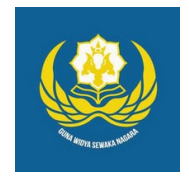

Jurnal Analogi Hukum

Journal Homepage: https://ejournal.warmadewa.ac.id/index.php/analogihukum

\title{
Akibat Hukum Kelalaian Pejabat Pembuat Akta Tanah (Ppat) Yang Tidak Melaporkan Bea Perolehan Hak Atas Tanah Dan Bangunan (Bphtb) Dalamperalihan Hak Atas Tanah
}

\author{
I Nyoman Agung Mas Dinata*, Pt. Gd. Seputra dan Luh Putu Suryani \\ Fakultas Hukum, Universitas Warmadewa, Denpasar, Bali-Indonesia \\ *masdinata@gmail.com
}

How To Cite:

Dinata, I, N, A, M., Seputra, P, G., Suryani, L, P. (2020). Akibat Hukum Kelalaian Pejabat Pembuat Akta Tanah (Ppat) Yang Tidak Melaporkan Bea Perolehan Hak Atas Tanah Dan Bangunan (Bphtb) Dalamperalihan Hak Atas Tanah. Jurnal Analogi Hukum. 2(1). 104-108. Doi: http://dx.doi.org/10.22225/.2.1.1622.104-108

\begin{abstract}
Development is essentially a process of continuous change in order to improve and progress toward the goals to be achieved. Fees for the acquisition of land and building rights, namely a tax on land / building rights, which in this case is referred to as a tax. In doing so, the PPAT can neglect by not reporting BPHTB in a transfer of land rights. Based on this, the title was raised. Then the problems arising from this study are: 1. How is the reporting arrangement for the acquisition of rights to land and buildings by the official land deed maker in the transfer of land rights? 2. What are the legal consequences for officials who make land certificates that do not submit reports on the acquisition of land and building rights? The method in this paper is a normative legal method, with literature study sourced from legal and secondary legal materials. The results obtained are the result of not carrying out an obligation in reporting taxes on land and building rights is the imposition of sanctions in the form of tax penalties and administrative sanctions in the form of fines.
\end{abstract}

Keywords: PPAT, Land, BPHTB

Abstrak-Pembangunaan pada hakekatnya merupakan proses perubahan terus menerus guna menuju perbaikan dan kemajuan ke arah tujuan yang ingin dicapai. Bea perolehan hak atas tanah dan bangunan yakni suatu pajak terhadap hak atas tanah/bangunan dimana dalam hal ini disebut sebagai pajak. Dalam pelaksanaanya, PPAT dapat melakukan kelalaian dengan tidak melaporkan BPHTB dalam suatu peralihan hak atas tanah. Berdasarkan atas hal tersebut maka diangkat judul. Maka timbul persoalan dari penelitian ini adalah: 1 . Bagaimanakah pengaturan pelaporan bea perolehan hak atas tanah dan bangunan oleh pejabat pembuat akta tanah dalam peralihan hak atas tanah? 2. Bagaimanakah akibat hukum bagi pejabat pembuat akta tanah yang tidak menyampaikan laporan bea perolehan hak atas tanah dan bangunan? Metode dalam penulisan ini adalah metode hukum normatif, dengan studi kepustakaan yang bersumber dari bahan hukumprimer serta bahan hukum sekunder. Adapun hasil yang didapat adalah akibat dari tidak dilaksanakannya suatu kewajiban dalam melaporkan pajak dari hak atas tanah dan bangunan adalah dikenakannya sanksi berupa sanksi perpajakan serta sanksi administrasi yang berupa denda.Dimana kedepannya diharapkan agar PPAT rutin melaksanakan kewibannya dalam hal melaporkan wajib pajaknya.

Kata kunci: PPAT, Tanah, BPHTB

\section{Pendahuluan}

Pembangunan yang merupakan tonggak awal dari sebuah perubahan suatu negara tak terlepas dari segala aspek yang berhubungan langsung dengan pembangunan tersebut guna tercapainya suatu keadaan atau kehidupan masyarakat yang adil dan makmur sesuai dengan sila ke 5 Pancasila. Banyak pembangunan dan fasilitas publik maupun pribadi yang banyak memerlukan lahan atau tanah yang luas, seperti halnya pembangunan dibidang industri, pertanian, pemukiman warga atau hal-hal yang lain.

Sebelum adanya Undang-undang Pokok Agraria yang selanjutnya disebut degan UUPA, terdapat dualisme hukum. Dualisme tersebut merupakan hak barat yang telah tercantum dalam KUHPer serta hak adat yang diatur 
dalam hukum adat.

Setelah berlakunya Undang-Undang Pokok Agraria tesebut dualisme yang dimaksud diatas telah dihapuskan, dan ditentukan bahwa semua peralihan hak atas tanah harus dilakukan di hadapan Pejabat Pembuat Akta Tanah atau PPAT. Peralihan hak atas tanah itu telah diatur dalam pasal 4 ayat (3) PP No.24/1997 tentang Pendaftaran Tanah, sbb :

untuk mencapai tertib administrasi seperti maksud dalam pasal 3 huruf $\mathrm{C}$, setiap bidang tanah dan satuan rumah susun termasuk peralihan, pembebanan dan hapusnya hak atas tanah dan hak milik atas satuan rumah susun wajib di daftar.

Hal yang sama juga dapat dilihat dalam pasl 37 ayat 1 perihal pemindahan hak :

peralihan hak atas tanah dan hak milik satuan rumah susun melalui jual beli, tukar menukar, hibah, pemasukan dalam perusahaan, dan perbuatan hukum pemindahan lainnya, kecuali pemindahan hak melalui lelang, hanya dapat didaftarkan, jika dibuktikan dengan akta yang dibuat oleh PPAT yang berwenang menurut ketentuan peraturan perundangundangan yang berlaku

Pemindahan hak atas tanah yang menyebabkan beralihnya suatu hak atas tanah tersebut, yang mana hal tersebut dilakukan dengan sadar oleh si pemegang hak atas tanah yang terdahulu. Beralihnya suatu hak atas tanah dan/ atau bangunan dapat dilakukan dengan cara seperti jual beli, hibah, waris, lelang, dan lain-lain.

Dihubungkan dengan pemungutan bea perolehan hak atas tanah dan/ atau bangunan, peralihan hak atas tanah tersebut tidak terlepas dari ketentuan Undang-Undang No.28 Tahun 2009, yang mana dalam Pasal 86 ayat(1) mencantumkan bahwa subjek dan wajib pajak dari hak atas tanah/bangunan tersebut merupakan subjek pribadi dan berbadan hukum.

Berdasarkan pemikiran diatas maka penulis tertarik untuk mengkaji sari segi hukum dengan menuangkannya dalam bentuk jurnal yang berjudul "Akibat Hukum Kelalaian Pejabat Pembuat Akta Tanah (PPAT) Tidak Melaporkan Bea Perolehan Hak Atas Tanah Dan Bangunan (BPHTB) Dalam Perlaihan Hak Atas Tanah".

Berdasarkan atas uraian diatas ,maka permasalahan yang akan dikemukanan adalah :

Bagaimanakah peraturan pelaporan bea perolehan hak atas tanah an bangunan oleh pejabat pembuat akta tanah dalam peralihan hak atas tanah ?, Bagaimanakah akibat hukum bagi pejabat pembuat akta tanah yang tidak menyapakan laporan bea perolehan hak atas tanah dan bangunan?

\section{Metode}

Tipe penelitian yang digunakan dalam melakukan penelitian ini adalah dengan menggunakan metode penelitian hukum normatif, yang mana pengkajiannya berdasarkan atas bahan-bahan hukum dan literatur. Dalam penelitian ini penulis menggunakan pendekatan perundang-undangan dan pendekatan konseptual. Pendekatan perundang-undangan ditelaah secara baik dan peraturan perundang-undangan tersebut juga berhubungan dengan masalah yang ada. Sedangkan pendekatan konseptual merupakan suatu pendekatan yang di dalam ilmu hukum ada dan berkembang pikiran serta doktrin dari para sarjana.

Sumber bahan hukum yang dipergunakan dalam penulisan ini bersumber dari bahan hukumprimer serta bahanhukum sekunder:

Bahan hukum primer, yang mana bahan hukum ini diperoleh dari peraturan perundangundangan, seperti UUD 1945, UU No 5 tahun 1960 tentang ketentuan pokok agraria (UUPA), Peraturan Pemerintah Nomor 24 Tahun 1997 tentang pendaftaran tanah, Peraturan Pemerintah Nomor 37 tahun 1998 tentang peraturan PPAT, PMNA 3 tahun 1997 tentang Peraturanpelaksanaan pendaftaran tanah, serta Perda Nomor 14 tahun 2010 tentang bea perolehan hak atas tanah dan bangunan.

Bahan hukum sekunder dalam penulisan ini yaitu bahan-bahan hukum yang diperoleh dari pengkajian kepustakaan (Library research) yaitu enggan membaca buku-buku hukum, jurnal-jurnal hukum, surat kabar dan juga dari internet yang berkaitan dengan permasalahan yang tengah dikaji berupa peralihan hak atas tanah.

\section{Hasil Penelitian dan Pembahasan}

\section{Pengaturan Pelaporan Bea Perolehan Hak Atas Tanah dan Bangunan Oleh Pejabat Pembuat Akta Tanah Dalam Peralihan Hak Atas Tanah}

Bea perolehan Hak atas Tanah dan Bangunan yakni pajak yang diberikan atas hak atas tanah maupun bangunan yang diperoleh oleh wajib pajak yang kemudian disebut pajak. 
Perolehanhak atas tanah dan atau bangunan ini adalah kegiatan dan perbuatan hukum yang mengakibatkan didapatkannya hak atas suatu serta hak atas suatu bangunan tertentu oleh orang perorangan tertentu maupun badan usaha.

Kemudian adapula sebutan Hak atas Tanah dan Bangunan itu sendiri adalah hak kepemilikan atas suatu tanah beserta isinya (bangunan yang berdiri diatasnya) sesuai dengan UUmengenai Peraturan Dasar PokokPokok Agraria, UU mengenai Rumah Susun serta diikuti dengan peraturanUU lainnya yang terkait.

Dalam Undang-Undang tentang Peraturan Dasar Pokok-Pokok Agraria, yang termasuk dalam hak atas tanah meliputi: Hak milik; Hak guna usaha; Hak guna bangunan; Hak pakai; Hak sewa; Hak membuka tanah; Hak memungut hasil hutan; dan

Hak lainnya yang terkait namun belum ditetapkan oleh undang-undang, serta hak-hak lain yang bersifat sementara.

Dalam ketentuan UU perpajakan yakni pajak daerah serta retribusi pemungutannya dialihkan dari pemerintah pusat ke pemerintah daerah. Sebelum UU tentang Pajak Daerah dan Retribusi Daerah ini diundangkan, Bea Perolehan Hak atas Tanah dan Bangunan merupakan pajak yang dibayarkan ke pemerintah pusat baru kemudian sebagian besar penerimaannya dibagi kepada kab./ kota yang tergolong juga dalam dana perimbangan. Namun hal tersebut sepertinya memberikan dampak pada pemerintahan didaerah dalam hal melaksanakan pelayanannya terhadap masyarakat. Bagaimana tidak, karena berdasarkan ketentuan yang ada dalam UU ini Sehingga jika seperti aturan sebelumnya pajak ini dibayarkan kepada pemerintah pusat, pemerintah daerah kabupaten/ kota hanya mendapatkan sebagian saja dari pajak-pajak yang dibayarkan oleh wajib pajak disetiap daerah.

Dalam Bea Perolehan Hak atas Tanah dan Bangunan terdapat juga subjek dan objek didalamnya, yaitu:

Subjek Bea Perolehan Hak atas Tanah dan Bangunan (BPHTB)

Suatu perbuatan hukum yang menyebabkan beralihnya hakatas tanah dan bangunan. Namun ada pula subyek pajak yang tidak dikenai BPHTB yaitu:

Petugas Diplomatik, Konsulat.
Negara sebagai pelaksanaan pembangunan dan kepetingan umum.

Badan Organisasi Internasional dimana salah satunya tidak melakukan usaha dan/ atau melaksanakan kegiatan diluar tugas dan fungsi yang diberikan.

Orang pribadi yang mendapatkan objek yang dikenai pajak tanpa perubahan nama.

Orang pribadi atau badan yang mendapatkan objek pajak karena wakaf.

Orang perorangan atau badan yang memperoleh objek pajak dan dipergunakan guna keperluanagama.

Objek Bea Perolehan Hak atas Tanah dan Bangunan (BPHTB)

artinya bukan tanah dan bangunannya secara nyata yang dikenakan Pajak Bumi dan Bangunan. Dengan demikian Bea Perolehan Hak atas Tanah dan Bangunan (BPHTB) merupakan peristiwa hukum perolehan hak atas tanah dan bangunan. Namun ada pula objek pajak yang tidak dibebani Bea Perolehan Hak atas Tanah danBangunan (BPHTB), yaitu:

Objek pajakyang diterima oleh perwakilan diplomatik dan konsulat.

Objek pajak yang diterima Negara untuk melaksanakan pembangunan bagi kepentingan masyarakat luas.

Objek pajak yangditerima Badan Organisasi Internasional yang telah ditetapkan dalam Keputusan Menteri Keuangan dengan beberapa syarat salah satunya tidak melaksanakan usaha atau melakukan acara diluar tugas serta fungsi yang diberikan.

Objek pajak yang diterima orang pribadi yang mendapatkan objek yang dikenai pajak tanpa perubahannama.

Objek pajak yang diterima orang pribadi atau badan beradasarkan wakaf.

Objek pajak yangditerima orang perorangan atau badan dan digunakan guna keperluan keagamaan.

Mekanisme pelaporan Bea Perolehan Hak atas Tanah dan Bangunan (BPHTB) menggunakan prodesur yang nantinya dijalankan atau diaksanakan oleh Bank yang sudah dilmpahkan tugas oleh Bendahara Peneria dalam melaporkan penerimaan pembayaran pajak Bea Perolehan Hak atas Tanah dan Bangunan (BPHTB) oleh wajib pajak. Prosedur ini juga termasuk hingga proses 
pelaporan yang harus dilakukan oleh Notaris/ PPAT atas setiap akta perubahan hak yang telah dibuat dan diterbitkan. Prosedur yang melibatkan Bank yang sudah ditunjuk ini mengharuskan wajib pajak membayar pajaknya ke rekening penerimaan kas daerah.

\section{Akibat Hukum Bagi Pejabat Pembuat Akta Tanah Yang Tidak Menyampaikan Laporan Beda Peroleha Hak Atas Tanah dan Bangunan}

Pelaporan BPHTB dewasa ini,masih saja PPAT lupa melaporkannya kepada kantor agraria itu karena seorang PPAT memiliki alasan tersendiri sehingga lupa untuk melaporkannya. Sehingga perlu diketahui akibat hukum apasaja yang diterima oleh seorang PPAT dalam halnya pelaporan BPHTB disini perlu di ketahui bahwa ada beberapa sanksi-sanksi hukum yang diterima apabila PPAT tidak melaporkan BPHTB, yaitu (Eugenia Liliawati Muljono, 1998 : 37) :

\section{Sanksi Perpajakan}

Self assessment system sudah diterapkan oleh pemerintah Indonesia untuk sanksi perpajakan. Dengan berlakunya sistem ini,wajib pajak dibebaskan serta dberikan kebijakan guna menyetor/ melunasi serta melapor pajaknya sendiri. Maka dari itu untuk bisa terlaksana dengan baik setiap wajib pajak di Indonesia wajib dan berhak mengerti dan mengetahui pengetahuan tentang perpajakan baik mengenai aturan tentang perpajakan hingga teknis administrasinya agar kedepannya dalam prakteknya di masyarakat bisa berjalan dengan tertib dan bebas dari masalah agar sesuai dengan target yang diinginkan. Jika melihat dari sisi Yuridisnya, keberadaan pajak itu sendiri memiliki sifat yang memaksa dan mengikat wajib pajak itu sendiri, maka jika nantinya wajib pajak lalai terhadap kewajibannya dalam membayar pajak akan timbul akibat hukum yaitu dikenakannya sanksi-sanksi perpajakan. Penerapan sanksi hukum ini sendiri dilakukan untuk menciptakan kepatuhan dari wajib pajak untuk membayarkan kewajibannya, sehingga untuk menghindari timbulnya konsekuensi hukum tersebut, wajib pajak perlu mempelajari dan mencari tahu apa saja konsekuensi hukum yang timbul apabila lalai dalam membayarkan pajaknya.

\section{Sanksi Administrasi Perpajakan}

Sanksi administrasi perpajakan ini biasanya timbul karena wajibpajak tidak melaksanakan kewajiban administrasinya sebagaimana telah tercantum dalam UU Perpajakan. Beberapa hal yang bisa menyebabkan timbulnya sanksi administrasi perpajakan ini adalah pertama wajib pajak melewati tanggal pembayaran yang sudah ditentukan sebelumnya dan yang kedua wajib pajak bisa kesalahan kalkukasi terkait jumlah pajak yang harus dibayarkan. Tujuan dari adaya sanksi administrasi ini adalah dianggap sebagai salah satu cara untuk menambah pendapatan negara terlebih sanksi yang diberikan tergolong dalam jumlah lumayan besar berdasarkan UU Tentang Ketentuan UmumTata Cara Perpajakan yaitu dinaikan sebesar $100 \%$ (seratus persen) atau $200 \%$.

\section{Perpajakan dalam sanksi pidana}

perpajakan biasanya timbul akibat wajib pajak tidak sesuai ketentuan, termasuk dalam tindak pidana perpajakan. Sanksi pidana ini diterapkan karena adanya unsur kesengajaan oleh wajib pajak dengan tidak membayarkan pajaknya, ini termasuk pelanggaran berat karena dapat merugikan besar terhadap pendapatan negara.

\section{Denda yakni sanksi administratif}

Jika wajib pajak tidak patuh terhadap kewajibannya dalam membayar pajak, sanksi administrasi berupa denda ini tergolong sanksi yang bisa dianggap mudah, hanya Jumlah denda yang harus dibayarkan wajib pajak akan teramat beragam tergantung dari tingkat kepatuhan seorang wajib pajakdalam melaksanakan kewajibannya guna memberitahukan, kemudian beberapa kententuan tentang sanksi denda ini tercantum didalam UU.

\section{Simpulan}

Diberikannya hak atas tanah maupun bangunan yang didapat wajib pajak Hakatas tanah ini merupakan kegiatan atau perbuatan hukum yang meyebabkan didapatkannya hak atas suatu serta hakatas suatu bangunan tertentu oleh orang perorangan tertentu maupun badan usaha. Maka dari itu tujuan Pengaturan Pelaporan berupa : a)Memberikan kewenangan yang lebih besar kepada Pemda dalam halperpajakan serta Retribusi; b) Meningkatkan akuntabilitas dalam penyediaan layanan; c) Memberikan kepastian bagi dunia usaha.

Akibat hukum PPAT dalam keterlambatan melaporkan BPHTB dapat dikenakan beberapa sanksi yang diterima apabila pejabat pembuat akta tanah tidak melaporkan berupa denda berupa sanksi perpajakan dan sanksi 
administrasi.

\section{Dafttar Pustaka}

Eugenia Liliawati Muljono, 1998, Peraturan Perundang-undangan Tentang Bea Perolehan Hak Atas Tanah dan Bangunan (BPATB), Cetakan Pertama, Harvarindo.

Undang-Undang No.28 Tahun2009 tentang Pajak Daerah danRetribusi Daerah

Peraturan Daerah No.14 Tahun 2010tentang Bea Perolehan Hak Atas Tanah danBangunan

Perda No.28 Tahun 2013 tentang Perubahan Atas Peraturan Daerah Nomor 14 Tahun 2010 tentang Bea Perolehan Hak Atas Tanah dan Bangunan 